\title{
Israel: Nova história e cinema pós-sionista
}

///////////////// Sheila Schvarzman ${ }^{1}$

1. Doutora em história social pela Universidade Estadual de Campinas. Tem pós-doutorado na área de multimeios. É uma das coordenadoras do grupo de pesquisa CNPq sobre Cinema Brasileiro: História e Preservação. Professora do Programa de Mestrado em Comunicação da Universidade Anhembi Morumbi. E-mail: sheilas@uol.com.br 


\section{Resumo}

O artigo aborda o movimento cultural e político que busca, através da revisão da história da criação de Israel, repor questões como o reconhecimento dos palestinos e a responsabilidade pelo seu exílio/expulsão. Dever de memória e de reconhecimento no qual o cinema israelense tem se engajado e para o qual o diretor Eyal Sivan propõe constituir arquivo de depoimentos dos perpetradores. Não só vítimas palestinas, mas combatentes, questionando assim, inclusive, as formas do documentário.

\section{Palavras-chave}

História e cinema, novos historiadores israelenses, cinema póssionista, Palestina, memória.

Abstract

This article discusses a cultural and political movement that seeks, by reviewing the history of the creation of Israel, to replace recognition of the Palestinians as well as the responsibility for their exile/deportation. Duty of memory and duty of recognition in which Israeli cinema is engaged, and to which filmmaker Eyal Sivan proposes constitute an archive with testimony of the perpetrators. Not only Palestinian victims, but especially Israeli perpetrators, questioning, too, the forms of documentary.

\section{Keywords}

History and cinema, new Israeli historians, post zionist cinema, Palestine, memory. 
São pouco expressivas na mídia as exibições de manifestações internas de descontentamento com as ações políticas dos governos de Israel contra os palestinos. No entanto, elas existem e têm levado à produção de filmes, sobretudo documentários, que interrogam essa realidade. Isso é o que se pode ver por dois filmes que concorreram ao Oscar de documentário em 2013. The gatekeepers, do israelense Dror Moreh, com o depoimento de cinco ex-diretores do serviço secreto, o Shin Bet, que se questionam e questionam ações que executaram, e 5 broken cameras, do israelense Guy Davidi e do palestino Emad Burnat, que, tendo comprado uma câmera para registrar o nascimento do filho, busca expor, através da violência reiterada cometida pelo exército israelense contra suas cinco câmeras, o que é o cotidiano palestino sob ocupação.

Assim, se a violência de Estado e as reações palestinas recrudescem, estão suscitando em parte da população israelense o reconhecimento dos palestinos e a construção de outras formas de Estado (binacional, dois Estados autônomos) que virão, e cuja história é preciso preparar - afinal, é uma história comum a ambos. Cineastas vêm se ocupando dela.

Essas preocupações, no entanto, não são novas e começaram a tomar corpo nos anos 1980 no cinema e na televisão quando diretores como Amos Gitai e David Perlov foram impedidos de veicular trabalhos seus encomendados pela televisão estatal. Naquele momento, o primeiro troca Israel pela França, e Perlov parte para um exílio interior com os Diários, nos quais filma o seu cotidiano: íntimo e político. Essa retração da política no espaço público, que 
2. As traduções para o português neste artigo foram feitas pela autora. corresponde a acontecimentos brutais, como a intervenção de 1982 em Sabra e Chatila, ocorre também quando está tomando corpo em Israel um forte movimento de revisão historiográfica, a partir da abertura dos arquivos sobre a constituição do Estado, em 1948.

Os palestinos, sua existência, sua imagem passam, desde então, a entrar para a história de Israel. E, se essa formulação parece absurda, ela marca bem a relevância do processo atual: no entendimento tradicional israelense, os palestinos não existem como identidade nacional autônoma, pois, sendo árabes como os sírios, libaneses, tunisianos, iraquianos, poderiam ser absorvidos por esses povos em seus territórios.

Essa formulação não é nova nem apenas israelense. É pensamento arraigado pelo colonialismo que se ocupou dessas terras desde o fim da Primeira Guerra, marcado pelo desprezo e desconfiança em relação aos orientais, como já mostrou Edward Said (2007). Assim, diante do fardo do homem branco do colonialismo inglês, as reivindicações sionistas ao território da Palestina vão encontrar boa recepção:

\footnotetext{
As quatro grandes potências estão engajadas em relação ao sionismo. E o sionismo, certo ou errado, bom ou mau, está enraizado numa longa tradição, nas necessidades atuais, nas esperanças futuras de uma importância bem mais profunda que a vontade e os preconceitos de 700.000 árabes que vivem agora nessa terra antiga (LORD BALFUR, 1919 apud GRESH, 2010, p. 66)².
}

Por outro lado, se esse processo vem transformando a percepção israelense sobre a existência dos palestinos e até mesmo levando ao reconhecimento da sua tragédia, a Nakba, a catástrofe que marcou a sua expulsão de territórios sobre os quais se construiu o Estado de Israel a partir de 1948; vem alterando também a visão sobre o que foi a chamada Guerra de Independência, quando, em maio de 1948, vários países árabes contrários a essa decisão, como o Egito, a Síria, a Transjordânia (atual Jordânia) Iraque e Líbano, além de grupos palestinos, invadiram o Estado nascente, que, além de rechaçar o ataque inimigo, teria expulsado palestinos de suas terras 
para ocupá-las (num processo de que a eliminação física dos antigos ocupantes não foi excluída).

Esses fatos e os seus personagens históricos (como o então primeiro ministro Ben- Gurion) estão na base da grande revisão que vem sendo empreendida desde os anos 1980 pelo que se convencionou chamar novos historiadores pós-sionistas. No mesmo período, cineastas produziram documentários que foram na mesma direção e questionaram, entre outros, a ocupação israelense, os usos e abusos da memória do Holocausto na constituição e justificação do Estado de Israel e da identidade israelense, até a constituição de um arquivo virtual de depoimentos de soldados e oficiais israelenses que participaram dessa guerra fundadora. Conforme apontou o cineasta Eyal Sivan, responsável pela construção desse arquivo em conjunto com o historiador Ilan Pappe, são os perpetradores da violência nas guerras, segundo Primo Levi, suas primeiras e mais bem situadas testemunhas. Elas devem falar.

O presente artigo pretende dedicar-se à discussão dessas significativas mudanças que vêm se manifestando com a construção de uma nova história e de um novo cinema em Israel, marcado este, sobretudo, pelas críticas à construção de uma cultura que, ao se inscrever como pioneira, civilizada e iluminista (isto é, ocidental no Oriente Médio), e ao mesmo tempo como vítima maior da humanidade, termina tendo como fundamento o apagamento da história e da existência do outro, de qual decorre a naturalização da opressão e mesmo da destruição desse outro incômodo. Tais questões vêm sendo construídas na imagem e em suas repercussões, com destaque para as obras de Eyal Sivan, que chamam a atenção para uma discussão pouco conhecida no Brasil.

\section{A velha e a nova história}

Para entender essa nova configuração, marcada pelo surgimento de revelações sobre violações israelenses na Guerra de Independência, é preciso levar em conta a existência pouco difundida na mídia de uma forte e contínua oposição política ao establishment. Partidos políticos e grupos de esquerda, movimentos de militares que se 
3. Independência em relação ao

Mandato Britânico, que nesse momento se retirava do território.

4. Vilarejo palestino onde mais de cem pessoas foram mortas pelos grupos paramilitares do Irgun e Lehi, facções de extrema direita, que foram muito criticadas pelo governo socialista da época.

5. O livro é o doutorado na Cambridge University. Em 2004, com nova documentação israelense e palestina, aumentam as evidências da responsabilidade pelo êxodo palestino tanto entre israelenses como entre os países árabes e as autoridades palestinas. recusam a servir em regiões palestinas ocupadas, ou o Paz Agora, buscam alternativas e, sobretudo desde os anos 1980, quando o relacionamento acadêmico entre israelenses e palestinos tornou-se mais intenso, permitem aos intelectuais israelenses conhecerem o conteúdo de trabalhos palestinos que até então eram considerados apenas como propaganda - principalmente com a abertura dos arquivos sobre a fundação do Estado, em 1948. Tudo isso levou ao aparecimento da nova historiografía pós-sionista, que, dispondo de novos documentos, passa a expor e criticar os fundamentos da constituição do Estado em que a Guerra da Independência e o êxodo dos palestino são temas centrais.

No relato historiográfico tradicional, depois da Partilha da Palestina decidida pela ONU em 1947, mas, sobretudo depois da Declaração de Independência do Estado de Israel, em 1948³, os Estados árabes contrários à decisão invadiram Israel, que lutou contra várias nações bem armadas. Esses países incitaram a fuga dos palestinos de suas terras para que não se tornassem alvo das batalhas, até o momento em que, vencida a guerra por eles, os palestinos retornariam. Portanto, os palestinos - que são árabes abandonam suas terras e vão para outros países árabes que poderão acolhê-los. Desse ponto de vista, não havia problema palestino, já que se partia do entendimento de que são árabes e como tal deviam ser acolhidos por seus irmãos. Entretanto, ainda que se soubesse que nessa fuga foram cometidas violências pelos combatentes israelenses em populações como Deir Yassin ${ }^{4}$, isso foi então considerado uma terrível exceção. A abertura dos arquivos pelos novos historiadores, como Benny Morris, que teve acesso aos diários de David BenGurion e que, em The birth of the Palestinian refugee problem 1947-1949 (1988) ${ }^{5}$, demonstrara que houve, sim, uma deliberada política de expulsão, certamente altera a percepção sobre os direitos dos palestinos. A análise da documentação e a escrita dessa história foram marcadas pela Guerra no Líbano e pela primeira Intifada, em 1987, quando começam a se acirrar em Israel as divisões ideológicas entre nacionalistas e o campo da paz (VIDAL, 2007).

Para Benny Morris ou Ilan Pappe (1988), tratava-se de revisitar as origens, observando como o movimento sionista, diante dos horrores sofridos durante o Holocausto, procurou reparar a barbárie 
6. À sombra de um gigante é um melodrama com estrelas da época como Kirk Douglas, Senta Berger, Angie Dickinson e John Wayne.
7. Haganá - do hebraico defesa designa o exército judaico ilegal, mas tolerado e parceiro dos ingleses durante a $2^{\text {a }}$ Guerra - antes da criação das Forças de defesa de Israel, a Tsahal, em maio de 1948. através da consolidação de um lugar de proteção. Entretanto, para que esse lugar surgisse, foi preciso desalojar outro povo. Essa nova história é escrita de um ponto de vista e com documentação basicamente israelense: fontes oficiais do governo, do exército, fontes inglesas e fontes privadas. Esse é o cerne das discussões e das novas descobertas, conforme a apresentação dos historiadores feita por Dominique Vidal e que, traduzidos apenas em 2008 na França, seguem inéditos no Brasil.

A Guerra da Independência foi construída na historiografia tradicional israelense como a batalha heroica de um pequeno e bravo povo praticamente desarmado contra um exército potente, numeroso e bem armado de várias nações árabes, que atacou o país de surpresa no momento em que comemorava a sua independência. Um duelo de Davi contra Golias, em suma. No filme americano A sombra de um gigante, de Melville Shavelson (Cast a giant shadow), de $1966^{6}$, podemos ter a mais viva expressão dessa visão. Ali, o povo pobre e impotente recém-saído do Holocausto, portanto fragilizado, se transmutava em combatentes aguerridos que, apesar da falta de recursos, e com a ajuda de um experiente militar judeu americano, conseguem vencer a batalha.

O filme trata especificamente da liberação da estrada que liga Tel Aviv a Jerusalém, palco de sangrentas batalhas entre israelenses e o exército formado por vários países árabes. Se no filme americano é a esperteza e a sagacidade de Mickey Marcos (Kirk Douglas) e seus comandados israelenses que conseguem formular uma estratégia para abrir caminho e religar o país para opor-se aos ataques inimigos, segundo os novos historiadores, ao contrário, a abertura desse caminho implicou o constrangimento, expulsões e até massacres da população palestina. Ilan Pappe (2012, p. 18) fala, inclusive, em limpeza étnica.

Ao contrário dessa mítica da fragilidade israelense, a documentação levantada por Benny Morris constata que parte dos armamentos israelenses havia sido tomada dos ingleses pela Haganá $^{7}$, quando seus membros participaram em operações conjuntas durante a Segunda Guerra. Além disso, contaram também com reforços dos russos. Quanto à falta de preparo, com 
a prática militar da Haganá e sua participação no exército inglês, se eram menos numerosos, estavam mais bem treinados e tinham o apoio político americano e diplomático e militar dos russos. Os árabes, ao contrário, que vinham de várias nações, não tinham treinamento, não sabiam operar o equipamento, que não era novo, e, sobretudo, não se entendiam.

O outro mito, decorrente do primeiro, diz respeito ao êxodo voluntário dos palestinos entre 1947-1949. Segundo as fontes oficiais israelenses, 500 mil palestinos abandonaram suas terras e propriedades, atiçados pelos países árabes que lhes pediam que abandonassem suas terras a fim de não se tornarem alvo na guerra; eles poderiam retornar a suas casas rapidamente, uma vez que os exércitos árabes venceriam o combate e riscariam Israel do mapa.

De acordo com a documentação levantada por Morris, no entanto, apenas 70 mil palestinos saíram voluntariamente. Simcha Flapan, em The birth of Israel: myths and realities (1987), observa ainda que, entre as terras designadas inicialmente para Israel na partilha da ONU em 1947 e as terras que Israel tomou durante a guerra, houve um acréscimo de 1/3 sobre o que estava designado aos palestinos.

Nesses trabalhos que dispensam o testemunho palestino, trata-se de olhar o interior da constituição do Estado e observar o quanto de propagandístico e ideológico havia na historiografia que surge concomitantemente ao Estado de Israel e em seu apoio. Ao mesmo tempo, e de maneira contraditória, pela significação que abarca, pelo caráter de causa e justificativa humana máxima para a obtenção de terras, de um lar, o Holocausto foi pouco abordado, como se o questionamento visasse mais exatamente o sionismo e a maneira como este se apropria do massacre nazista para reforçar a existência do Estado, deixando de lado muitas vezes a compreensão das questões que estão na imbricação trágica de dois destinos: o judeu e o palestino.

Do ponto de vista da recepção dessas várias obras em Israel, vale observar que todos os autores são israelenses e se graduaram em Israel, embora a maioria dos trabalhos tenha sido escrita em doutoramentos nos Estados Unidos e na Inglaterra, onde foram 
inicialmente publicados. Os livros desses historiadores, começando pelo de Benny Morris, de 1988, tiveram ampla repercussão em Israel, e, como vimos pelos títulos e pelas datas, continuam a ser lançados, apaixonadamente criticados pelos outros historiadores, mas encontram entre os intelectuais pacifistas, e no jornal Haaretz, um lugar de apoio e divulgação.

A questão da responsabilidade pelo êxodo palestino, tema do livro de Benny Morris, causou impacto e foi para os meios de comunicação no ano mesmo de seu lançamento, 1988, que coincidiu com o da comemoração dos 40 anos de Israel. Aliado à declaração do Estado palestino, conduziu até mesmo a mudanças nos livros didáticos israelenses, que começaram a tocar nessa e em outras questões. Entretanto, com os revezes depois do assassinato de Rabin em 1995 e da frustração com Camp David em 2000, Ariel Sharon, em 2001, então no poder, os tirou de circulação. Essa censura põe a nu, em primeiro lugar, o caráter controverso da democracia israelense e, paralelamente, a persistência das narrativas históricas tradicionais, reforçadas agora pelo recrudescimento do campo nacionalista, que alimentou a expansão da implantação de colônias em território ocupado, tendo na justificativa bíblica e religiosa os seus indiscutíveis argumentos.

Em 2004, de posse de novos documentos palestinos e israelenses, Morris lança uma nova versão do seu livro na qual reforça os seus argumentos sobre o plano de Ben-Gurion de transferência da população palestina para os países árabes, ação que teria se realizado durante a Guerra de Independência. Entretanto, pelas dificuldades de diálogo com os palestinos, que nesses anos também retomaram ações violentas, marcadas, sobretudo, pelas posturas do Hamas, Benny Morris mudou radicalmente suas opiniões, uma vez que entende que os palestinos não estão interessados em um Estado binacional, mas em um único Estado palestino que não inclui Israel (BEN-SHIMON, 2012).

Esses questionamentos podem ser notados também no cinema israelense, e o mesmo destino de errância também pode ser observado entre os cineastas que, como os historiadores, mantêm ligações fora de Israel para financiar e divulgar os filmes, já que em seu próprio país os trabalhos são vistos com restrição e críticas negativas - isso quando são vistos. 


\section{O questionamento das imagens}

São conhecidos no Brasil os trabalhos de Amos Gitai, cujas ficções, como Kedma (2002), que tratam desse mesmo período, tiveram exibição comercial, mas também muitos dos seus documentários foram exibidos em mostras. Certamente Bait (Casa), de 1980, encomendado e proibido pela televisão estatal, se tornou emblemático por ter mostrado pela primeira vez a história de uma casa em Jerusalém que era originalmente de palestinos, foi apropriada pelo governo depois de 1948 e finalmente vendida em 1977. Fala, portanto, ainda em 1980, da mesma história e dos mesmos mitos que vão interessar aos novos historiadores: a Guerra de Independência e o êxodo palestino, de uma perspectiva da micro-história. O filme foi censurado e teve a exibição proibida. Conforme lembra o diretor: "Em 1980 não se falava, não se admitia, não se imaginava que as casas que os israelenses ocupavam haviam tido uma vida anterior àquela que os judeus conheceram" (TOUBIANA, 2004, p. 118).

O documentarista Eyal Sivan (1964) tem uma postura política mais radical. Como Gitai, teve problemas na recepção de seus filmes em Israel e foi para Paris, onde foi criticado pelos antigos nouveau philosophes Alain Finkelkraut e Bernard Henri Levi, que o acusaram de antissionista, o que ele é realmente, e de antissemita. Mudou-se para Londres, onde é professor universitário e produz filmes em que aprofunda os questionamentos anteriores e percorre uma senda muito próxima à dos novos historiadores, uma vez que trabalha com os usos políticos do passado na conformação da identidade israelense e do Estado de Israel. Mas também com aquilo que do passado foi varrido pelo esquecimento, ocultado como a própria natureza da Guerra de Independência e do êxodo palestino.

Entre 1991 e 1999, realizou dois filmes que interrogam os usos da memória coletiva do Holocausto em Israel. Izkor: slaves of memory (Escravos da memória), em 1991, e, em 1999, The specialist (O especialista), sobre o julgamento de Adolf Eichman em Israel. Ali, Sivan retomava as duras críticas de Hanna Arendt, que, em seu livro de 1963, apontava o uso político do julgamento 
8. Disponível em: <http://www. youtube.com/watch? $\mathrm{v}=4 \mathrm{Cgb}-$ VbL7dA $>$. Acesso em: 18 jul. 2012. de Eichman como um espetáculo com vistas à formação de uma consciência judaica que parte significativa da população israelense, composta por judeus vindos de países orientais, desconhecia. Essa consciência deveria estar centrada no Holocausto e no seu significado para a existência de Israel. Por seu conteúdo, o livro de Arendt, lançado em 1963 nos Estados Unidos, só foi publicado em Israel em 2000, um ano depois do lançamento do também criticado filme - que interroga o uso da memória do Holocausto na formação da consciência política israelense.

Em 2009, dirigiu Jaffa, a mecânica da laranja, ${ }^{8}$ em que desmonta um símbolo de Israel e do progresso que trouxe à região, as laranjas Jaffa, que seriam resultado das transformações modernizadoras de sua agricultura e de seus homens novos. As imagens que Sivan encontra mostram como a mesma laranja Jaffa vinha de uma cidade palestina de mesmo nome, conhecida por seus laranjais. Através de farto material iconográfico, de entrevistas com especialistas israelenses e palestinos, além de agricultores e antigos moradores, mostra a história da cidade palestina de Jaffo, tomada por Israel - e junto com ela os laranjais e até mesmo a marca Jaffa, nacionalizada pelo governo socialista então no poder. O filme faz da laranja e da cidade palestina uma enfática metáfora da apropriação das terras, da cultura, da economia e do símbolo palestino por Israel em 1948, indicando o apagamento de uma história que faz retornar em suas imagens. Mais: a documentação fotográfica e cinematográfica, além das entrevistas, dizem respeito à cooperação entre diversos povos em sua produção e comercialização.

A construção fílmica nessas obras incide sobre a história e apropriação do passado como um dispositivo de poder, conforme Foucault. Para fazê-lo em Izkor: slaves of memory de 1991, por exemplo, ele observa práticas culturais como as comemorações, desmontando os mecanismos que atuam através delas. Com a participação de um intelectual de prestígio em Israel, Yeshayahu Leibowitz, que é entrevistado e que dá o tom e, sobretudo a autoridade às críticas feitas, o diretor produz um documentário expositivo que registra a comemoração escolar (do maternal ao final do segundo grau) de várias efemérides do calendário 
concentradas em abril, momento em que se deve lembrar Izkor. O filme registra as festividades nos vários graus da escola. O que se rememora são os momentos de opressão passados pelos judeus nas diferentes épocas históricas que as festas evocam - sem que se busque entender as razões disso. As comemorações se somam em sua continuidade cronológica, começando com a Páscoa, que marca a saída de Moisés do Egito, passando pelo Holocausto e pela Guerra de Independência, até a Declaração de Independência de Israel, construindo nessa sobreposição de festas uma relação entre as perseguições, o antissemistismo e a necessidade de criação de um lugar de abrigo, um lar para os judeus. Mas servem, sobretudo, segundo Leibowitz, para justificar as políticas e ações de Estado, na medida em que a necessidade da existência de Israel se confunde com os governos e políticas praticadas. Para mostrar isso, Sivan se detém longamente na comemoração da Páscoa numa classe do maternal, na qual as crianças escutam os relatos sobre as perseguições, os sofrimentos e a saída do Egito. A câmera espia o que se passa na sala de aula e em séries subsequentes com as festas seguintes, deixa aparecer o caráter emotivo e pouco racional das comemorações nos diferentes graus da escola e em família: num sistema repetitivo e reiterativo em que se conforma a identidade como povo perseguido, isolado que precisa se proteger contra os inimigos. Ontem como hoje. A essa sucessão de emoções pouco racionalizadas, revividas a cada ano na escola e reiteradas - a maior delas, com a visita ao Museu do Holocausto - , segue justamente a grande e alegre comemoração da Independência de Israel, solução das perseguições e fecho radioso do triste destino. Portanto, o que fica como mensagem reforçada a cada ano pelas comemorações é a necessidade de existência do Estado com a sua política vigente que mantenha Israel, o lugar dos perseguidos. Assim, da necessidade justa da existência de um Estado autônomo passa-se à justificativa da manutenção de uma política de Estado, mas também da conformação de uma identidade pelo isolamento dos outros povos.

É em Jaffa, a mecânica da laranja, de 2009, que esse procedimento é ainda mais intenso. A escolha do título, evocando o filme de Stanley Kubrick, não é gratuita, pois é de violência que se trata, como se poderá ver. O documentário é expositivo, 
9. Os ingleses ocupam a Palestina a partir de 1917. organizado a partir de vasto material de arquivo, como fotos, filmes, propagandas, rótulos e imagens várias, que são comentados por historiadores, pesquisadores de imagens e pintores, assim como agricultores envolvidos com o cultivo de laranjas, sempre palestinos e israelenses, acompanhados de músicas das épocas enfocadas. Partindo desse vários testemunhos, que muitas vezes contrapõem diferentes pontos de vista, Sivan reconstrói a história de Jaffo, um importante porto palestino, e de suas perfumadas laranjas, que eram dali exportadas para a Inglaterra9 ${ }^{9}$, lembrando não só o colonialismo de que são parte mas também o orientalismo que recobre a imagem desse produto e desses lugares, vendidos como exóticos desde o século XIX. Ao contrário disso, a Israel sionista vai se constituir sobre o mito da modernidade - o Ocidente no Oriente - , do progresso e dos esforços que levam ao desértico Oriente a fertilidade e o esplendor de um passado longínquo. Isso significava dizer que até o início do século XX, quando começa o retorno de populações judaicas, as terras eram virgens, ou que ninguém se ocupava convenientemente delas. Assim, as laranjas Jaffa são o resultado, a prova do sucesso desse árduo e necessário trabalho. Corroborando essa imagem de uma terra que clamava pelo seu resgate, desde 1840, um ano depois da invenção da fotografia, fotógrafos europeus enquadravam paisagens supostamente bíblicas como desérticas, mostrando assim a necessidade de conquista. As imagens produzidas pelo sionismo décadas mais tarde vão projetar a ideia dessa arrancada: nos filmes, as propagandas se constroem como num western, com tratores revolvendo a terra, muitas imagens em contra plongée, imagens próximas também à retórica dos filmes soviéticos, caros aos sionistas trabalhistas.

No entanto, como o filme vai mostrar, o cultivo das laranjas era anterior à instalação do Estado judeu e contou com a colaboração de muçulmanos, cristãos e judeus que conviveram na atividade, não sem conflitos, mas chamando a atenção para uma cooperação que foi possível, e até mesmo para um reconhecimento mútuo que deixa de existir a partir de 1948. E, como lembra um agricultor palestino, "toda a Palestina exportava laranjas com o nome de Jaffa. E hoje não há mais nenhuma laranja em Jaffo"10.
10. Jaffo foi destruída na guerra de 1948 e transformada em um bairro de Tel Aviv. 
Segundo os testemunhos de israelenses e de palestinos que trabalhavam na atividade, a instalação do Estado judeu em 1948 coloca um ponto final na convivência. Apenas $5 \%$ dos palestinos ficam em suas terras (os outros saíram, foram expulsos...). Os laranjais tornam-se propriedade do Estado. Um antigo proprietário palestino torna-se empregado nas suas próprias terras, agora apropriadas por Israel, assim como as laranjas Jaffa, que se tornam o emblema do novo Estado ensolarado e seu principal produto de exportação. Nas propagandas sionistas podem-se ver homens e mulheres jovens que colhem laranjas usando shorts e mostrando corpos esbeltos, enquanto mulheres cobertas da cabeça aos pés imagem de palestinas - carregam fardos. A ideia da modernidade contra o atraso é reforçada e viaja mundo afora junto com as laranjas Jaffa. E a história da tragédia palestina, da Nakba, do êxodo e de sua própria existência naquelas mesmas terras é apagada. Essa história, essa convivência que foi possível foi enterrada. O reconhecimento da existência do outro, negada.

Na mecânica da laranja, como se vê, houve muita violência, uma violência que se construiu pela usurpação, mas, sobretudo pelo apagamento da existência do outro, pela sua imagem como negativa, atrasada. E é isso que o filme capta, ainda que se deva chamar a atenção para certo maniqueísmo de Sivan quanto à apresentação desprovida de conflitos entre os palestinos, contra a violência simbólica ou concreta, sempre unívoca nos documentos israelenses.

Assim, pode-se criticar em Eyal Sivan um partidarismo, até mesmo pela falta de documentos palestinos que pudessem dar uma ideia da imagem que eles construíam sobre os judeus que vinham se instalando ali desde 1917, com o Mandato Britânico. As imagens, assim como a história palestina, estão espalhadas, enterradas e é justamente essa falta da imagem palestina que dá à imagem israelense a sua força e preponderância no imaginário. Como lembra Ilan Pappe, é justamente pela falta de arquivos palestinos sobre a Nakba que relatos orais são indispensáveis, mas também os próprios arquivos israelenses sobre a guerra de 1948 (2012). 
11. Disponível em: <http:// www.youtube.com/user/ towardcommonarchive/videos $>$. Acesso em: 16 fev. 2013.

12. Disponível em: <http://zochrot. org/en>. Acesso em: 16 fev. 2013.
Ora, se os arquivos israelenses contêm a história da catástrofe palestina, como mostraram as obras dos novos historiadores, é chegado o momento de registrar não apenas os relatos dos palestinos que há décadas expõem, com sua errância e segregação, as várias faces e a dolorosa progressão desse processo mas também os combatentes israelenses que ainda estão vivos, o Outro dessa catástrofe.

Desde 2005 Sivan vem entrevistando ex-combatentes israelenses dessa guerra. Os perpetradores, como prefere denominá-los. Fazendo a diferenciação proposta por Primo Levi (2000) entre as testemunhas e os perpetradores, aqueles que lutaram do lado vencedor, vem procurando, através deles, o discurso do poder. As formas do conflito, as razões. A lógica que os mobilizava. Os relatos sobre as expulsões, a violência. Em 2012, várias dessas entrevistas constituíram o acervo Rumo a um arquivo comum - Palestina 1948, que se configurou numa exposição em Tel Aviv, num pacote de DVDs com esses testemunhos, e num site na internet com parte dessas entrevistas ${ }^{11}$, cuja edição foi financiada pela Zocrot, uma organização não governamental que trabalha em Israel pelo reconhecimento e reparação da tragédia palestina $^{12}$, pela universidade de East London e pelo Arts and Humanities Research Council.

Sivan ainda não se preocupa com reparações. Sabe que fazer filmes é produzir documentos, uma memória contra o esquecimento. Com isso, "quer formar uma base para a verdade, sem a qual uma futura reconciliação não poderá ocorrer" (SILVER, 2012).

Por isso, propõe mudar o foco. O documentário tradicionalmente ouve a vítima e com ela salva o espectador que, ao participar desse ritual confessional (e pactuar com ele) que Sivan define como cristão, de fazer o outro falar, assevera ao espectador o seu papel de alguém que está do lado certo. Essa mudança de perspectiva deve mudar também o lugar do espectador. Interrogá-lo para saber o que faria e saber afinal, segundo Sivan, o que você é? (SILVER, 2012).

Ouvir o perpetrador não só confirma aquilo que a vítima já disse como mostra as ações da perspectiva de quem as praticou. 
Para Sivan, não se trata de dar lugar às justificativas. Ao contrário, trata-se de ouvir o discurso do poder e da força para que o espectador possa entender sua mecânica. Não a dor da vítima que sempre encontra a compaixão do espectador reiterando o aspecto melodramático e a teatralidade do documentário testemunhal, mas o discurso, e, podemos acrescentar, as contradições daquele que domina pela força. É só a partir do conhecimento amplo sobre esses testemunhos que, segundo Sivan, se poderá chegar a um reconhecimento de ambas as partes:

Há a narrativa sionista e a narrativa palestina, como se as duas pudessem coabitar. Para sair do conflito conflito de memória, o conflito sobre a história - o único caminho é encontrar uma narração conjunta. [...] Os depoimentos dos perpetradores serão acompanhados pelos testemunhos dos palestinos e, assim, poderemos chegar a uma narrativa que se baseie em uma história que seja reconhecida como comum a ambos. Ser capaz de concordar que uma história comum implica algo para o futuro, como um Estado comum (SILVER, 2012).

\section{Rumo a um arquivo comum}

Nos relatos reunidos no site, estamos diante de homens de em torno de 85 anos, nascidos em Israel ou fugidos da Europa na Segunda Guerra. São pessoas que em sua maioria vivem em kibutzim, como viveram na época dos fatos que vão narrar. Isso significa que em sua maioria eram socialistas ou comunistas, e pertenciam às brigadas armadas da Haganá e do Palmach, que vão depois constituir o exército regular de Israel. São relatos diante de uma câmera fixa, com o entrevistador oculto, que interpela. Os homens estão sentados em sofás, na mesa da cozinha. Tinham em torno de 18 a 20 e poucos anos. Essas informações aparecem na tela no início de cada depoimento e informam o nome, a data de nascimento, o grupo armado e o lugar onde atuaram. Registram também a data da gravação e a duração original dos depoimentos, que têm em geral de 50 a 90 minutos, e o tempo de edição, que é de cerca de 15 minutos, superior ao que se pode ver no site. $\mathrm{O}$ relato mais interessante está na íntegra. É de Binyamin (Roski) Eshet. 


\section{Eles falam:}

13. Partido sionista chalutziano (favorável à vida nos kibutzim), de tendência comunista.
Amós Harpaz relata a saída de palestinos de uma cidade próxima ao kibutz onde vivia. Recorda-se com pesar da massa de gente que saía em fila. Sivan pergunta o que ele achava daquilo:

- Eu era do Hashomer Hatzair ${ }^{13}$, que acreditava em um Estado binacional... Ficamos com mais terras, mas não foi intencional, foi um resultado da guerra.

Avir Yáari:

S.: - Quem disse para eles saírem?

A.: - O exército israelense.

S.: - Como foram evacuados?

A.: - Em caminhões. Entrávamos, e eles fugiam. Fugiam de medo dos judeus por causa de Deir Yassin. Tinham muito medo.

Dov Haklay:

- Tínhamos que limpar a área. Entramos em várias comunidades árabes, não para conquistá-las. Passávamos através da população, e eles não ofereciam resistência. Eu patrulhava para ter certeza de que a área estava limpa, limpa de árabes. Eu me lembro de um lugar onde tivemos que usar a força para retirá-los. Não me lembro do nome. [...] não iríamos fazer guerra com eles, mas, se não saíssem, teríamos que atacar. Então eles saíram. Mas eles não queriam sair. Eles explicavam que tinham terras, culturas e não queriam abandoná-las. Era muito triste.

Shmuel e Bat Sheva Grosfeld, poloneses que fugiram da guerra:

Shmuel: - Eu não queria essa guerra, mas aconteceu, e eu acho que foi bom para os sobreviventes do Holocausto em particular. Toda essa coisa do Holocausto ficou para trás e, à frente, o futuro, a construção do nosso lar. Foi como se tivéssemos renascido aqui.

Bat Sheva: - Aqui é a nossa casa e protegemos a nossa casa. Não ficou nada para nós lá atrás. Perdemos tudo.

Shmuel: - Tento pensar no que aconteceu, no significado disso.

Dubi Goldshmit: 
- Ver uma caravana enorme de gente saindo não é coisa boa de ver. É difícil. Mulheres, crianças, gente de todas as idades, animais, e de repente eles desapareciam para um futuro incerto. Seus irmãos não os aceitavam. O campo de refugiados está aí até hoje. Não vamos nos meter nessa história. Eles usam os refugiados como uma arma contra nós. Isso é uma outra história.

Sivan pergunta a Micha Lin o que quer dizer limpar a região:

- Tornar a coisa de uma forma que não queiram ficar ali.

S.: - Como fazer isso?

M.: - É mais fácil do que você pensa. Depois eles saíram e não era coisa bonita de ver. Primeiro era de noite, depois houve um tiro. Nós não atiramos. Acho que foram eles. Depois eles se foram na direção de Jenin, e tudo acabou para nós. Começava um novo período.

S.: - Vocês se alegraram?

M.: - Não, guerra é guerra, e nós estávamos lutando pelas nossas vidas.

Binyamin (Roski) Eshet: - Alguém obrigou os palestinos a cavar fossas onde depois pessoas foram mortas e enterradas. Foi horrível, mas eu estava lá, sim. Pessoas se apoderaram dos bens das pessoas expulsas. Mas eu não.

Lembra-se com pesar, emoção.

Os trechos das entrevistas no site têm de 4 a 15 minutos e se detêm no testemunho sobre a responsabilidade dos combatentes, a sua forma de participação. Os relatos, tais como estão editados, correspondem aos momentos cruciais de que participaram. São como confissões, ainda que poucos admitam a própria participação em ações que descrevem atos de grande violência. Sempre foi outra pessoa, embora por vezes afirmem que mataram pessoas e que não se esquecem disso. Todos sem exceção se referem a limpar a área, limpar a área de árabes, depois eles fugiram, foram expulsos e depois as casas foram demolidas. E depois ficamos felizes, ficamos aliviados. Começava uma nova vida para nós. 
14. Disponível em: <http://eyalsivan. info/index.php?p=elementsl\&id=4\# \&panel1-5>. Acesso em: 16 fev. 2013.
Sivan direciona os relatos com suas perguntas, interpela e interrompe o fluxo das lembranças que trazem também sentimentos contraditórios, pesar, ainda que esse não seja o afeto buscado, que se pode ver pela edição.

\section{Enquadrando perpetradores}

Enquadrando perpetradores (framing perpetrators) é como Sivan nomeia esse exercício de filmar o executor. E enquadrar tem mais de um sentido, pois significa colocar em quadro numa filmagem, mas também determinar o crime, deter para averiguações, conforme o Houaiss, dar castigo, punir, tornar obediente, sensato; pôr nos eixos; disciplinar. Suas imagens estão fazendo isso. Estão enquadrando os velhos senhores como cúmplices de atos passíveis de julgamento. Os espectadores tomam o lugar de juízes ou daqueles que encontram justificativas para absolvê-los, para minorar o alcance e o sentido desses crimes, até que os depoimentos tenham uso formal e judicial. Dever de memória para com os palestinos e para com a história israelense. É para isso que estão sendo preparados. Entretanto, isso ainda não parece muito próximo, uma vez que, em Israel, a exposição na qual se mostravam esses filmes teve pouca repercussão. $\mathrm{Na}_{\text {mídia }}{ }^{14}$, só chamou a atenção de um repórter de um jornal de direita, que criticou o evento e o material, o que demonstra a absoluta rejeição ao tema, a cegueira completa, apesar dos depoimentos explosivos que contém. E a própria noção de real é mais uma vez questionada. Diante da guerra de memórias, da imposição e hegemonia das narrativas, de que vale então a imagem? O testemunho? Não mudam nada?

Os opositores sempre poderão dizer - como fizeram - que os depoimentos estão a serviço da causa e, sobretudo, da propaganda palestina Pode-se objetar, no entanto, que estão excessivamente editados, uma vez que esses senhores que falam de livre e espontânea vontade estão produzindo materiais que os incriminam. Assim, seria conveniente ter a íntegra dos depoimentos, ainda que, como lembra Sivan, não se trata de produzir justificativas. 
Temos aqui uma ação militante em mais de um sentido. Ela se configura como o reverso do relato da vítima. Mas é também o caminho para o reconhecimento do outro, gesto fundamental para algum vislumbre de paz. Para a recuperação da memória e história palestinas, e até quem sabe para uma reparação. Um uso deliberado e consciente de tomar o cinema como arquivo de memórias para constituir uma outra história, quem sabe comum, como prega Sivan. 


\section{Referências}

BEN-SHIMON, C. “Benny Morris on why he's written his last word on the Israel-Arabconflict". Haaretz, 20 set. 2012.

FLAPAN, S. The birth of Israel: myths and realities. Londres: Croom Helm, 1987

GRESH, A. De quoi la Palestine est-elle le nom? Paris: Les liens qui libèrent, 2010.

LEVI, P. É isso um homem? Rio de Janeiro: Rocco, 2000.

MORRIS, B. The birth of the Palestinian refugee problem: 19471949. Cambridge: Cambridge University Press, 1988.

. "Survival of the Fittest". Haaretz Maganize, 9 jan. 2004.

PAPPE, I. Britain and the Arab-Israeli conflict: 1948-1951. Londres: Taurus, 1988.

. "A common archive of the future". In: Towards an archive. Vídeo Testemonies of Zionist Fighters in 1948. Tel Aviv: Zochrot, 2012.

SAID, E. Orientalismo. São Paulo: Cia. das Letras, 2007.

SILVER, C. "Against forgetting: an interview with Eyal Sivan”. Al Jazeera.com, 12 nov. 2012. Disponível em: <http://www.eyalsivan. info/index.php?p=elements2\&id=26\#\&panell-3>. Acesso em: 16 fev. 2013

TOUBIANA, S. Amos Gitai: percursos, exílios e territórios. São Paulo: Cosac Naif, Mostra Internacional de Cinema de São Paulo, 2004.

VIDAL, D.; BOUSSOIS, S. Comment Israel expulsa les palestiniens (1947-1949). Paris: Atelier, 2007. 